\title{
Preliminary results of a study of magnetic properties in the Foum-Zguid dyke (Morocco)
}

\author{
P.F. Silva ${ }^{\text {a,b,* }}$, F.O. Marques ${ }^{\text {c }}$, B. Henry ${ }^{\text {d }}$, A. Mateus ${ }^{\text {e }}$, N. Lourenço ${ }^{\text {f }}$, J.M. Miranda ${ }^{\text {a }}$ \\ ${ }^{a}$ Dep. Física and CGUL, Fac. Ciências, Univ. Lisboa, Edifício C8, Piso 6, 1749-016, Lisboa, Portugal \\ ${ }^{\mathrm{b}}$ ISEL-Rua Conselheiro Emídio Navarro, 1-1950-062 Lisboa, Portugal \\ ${ }^{c}$ Dep. Geologia and CGUL, Fac. Ciências, Univ. Lisboa, Edifício C2, Piso 5, 1749-016, Lisboa, Portugal \\ d Geomagnetism and Paleomagnetism, IPGP and CNRS, 4 av. de Neptune, 94107 Saint-Maur Cedex, France \\ e Dep. Geologia and CREMINER Fac. Ciências, Univ. Lisboa, Edifício C2, Piso 5, 1749-016, Lisboa, Portugal \\ ${ }^{\mathrm{f}}$ Centro de Investigação Marinha e Ambiental da Universidade do Algarve, Portugal
}

Received 30 July 2003; received in revised form 9 January 2004; accepted 26 January 2004

\begin{abstract}
This work focuses on the study of flow and propagation of magma using rock magnetic analyses along sections across the thick Jurassic dyke of Foum-Zguid (Southern Morocco). Thermomagnetic data show that Ti-poor titanomagnetite is the main magnetic carrier. Petrographic analysis shows that the main Ti phase (ilmenite) occurs either as lamellae within spinel (center of the dyke) or as isolated grains (dyke margin). Bulk magnetic properties display distinct behavior according to the distance to the dyke margin; grain size of the main magnetic carrier decreases towards the center of the dyke, while the natural remanent magnetization and the bulk magnetic susceptibility increase. Only the magnetic susceptibility ellipsoid close to the dyke margin corresponds to that usually found in thin dykes, with the magnetic foliation sub parallel to dyke margins. Maximum principal axis is in most cases either parallel or perpendicular to the intersection between the planes of magnetic foliation and dyke wall. Moreover, when this axis is perpendicular to the intersection it is associated with a more oblate magnetic susceptibility ellipsoid shape, indicating the presence of complex magnetic fabrics. The studied magnetic properties show that, in this $100 \mathrm{~m}$ wide thick dyke, flow structures related with dyke propagation are only preserved close to the quickly cooled dyke margins.
\end{abstract}

(C) 2004 Elsevier Ltd. All rights reserved.

Keywords: Dyke emplacement; Magma flow; Magnetic properties; Mesozoic magmatic provinces

\section{Introduction}

Although magmatic flow and propagation through fractures is the most efficient means of moving magma from magma sources across cold lithosphere, the mechanics of these processes is yet not quite well understood (Rubin, 1995, 1998). The anisotropy of the magnetic susceptibility (AMS) is one of the methodologies that during the last two decades has most contributed

\footnotetext{
${ }^{*}$ Corresponding author. Address: ISEL-Rua Conselheiro Emídio Navarro, 1-1950-062 Lisboa, Portugal. Fax: +351 217500977.

E-mail address: pmfsilva@fc.ul.pt (P.F. Silva).
}

for a better understanding of these processes. On the other hand, most studies on dykes have been carried out in relatively thin $(<20 \mathrm{~m}$ width) and sub-superficial dykes. The present study was carried out on a thick and deep-seated dyke.

Khan (1962) verified the existence of a relationship between AMS and the preferred orientation of the long axes of magnetite grains of some igneous and metamorphic rocks. Hargraves et al. (1991) showed that AMS is related with the grain distribution promoted by the fluid dynamics and fabric of the igneous rocks. AMS measurements were then often used because of the sensitivity and accuracy of this method to find statistically whole 
rock preferred mineral orientation. Igneous rocks were in fact the main reason for the AMS development, once the traditional approaches were of difficult application and much time consuming to infer rock petrofabric, resulting from a nearly isotropic grain distribution.

The essential work of Knight and Walker (1988), in nearly isotropic mafic dykes at the Koolau Complex (Ohau, Hawaii), confirmed the congruency between the orientation of the principal axes of the magnetic susceptibility ellipsoid and the macroscopic flow related structures. Nowadays, AMS is one of the most applied methods to infer petrofabric related with magma flow, helping in the characterization of the complex intrusion processes within the lithosphere in distinct geodynamic settings (e.g. Staudigel et al., 1992; Raposo, 1997; Varga et al., 1998; Rochette et al., 1999; Aifa et al., 1999; Aifa and Lefort, 2001; Callot et al., 2001; Callot and Guichet, 2003; Geoffroy et al., 2002; Archanjo et al., 2002).

However, the correct interpretation of AMS in dykes is not always straightforward. Rochette et al. (1991, 1999) and Tauxe et al. (1998) distinguished between normal and abnormal magnetic fabrics. The normal magnetic fabric is characterized by the minimum susceptibility axis $(K 3)$ sub-perpendicular to the dyke wall (i.e. magnetic foliation sub-parallel to the dyke wall). The abnormal fabric could be subdivided in intermediate (exchange of maximum $(K 1)$ with the intermediate susceptibility ( $K 2)$ or $K 2$ with $K 3$ relative to normal fabric) and inverse (exchange of $K 1$ with $K 3$ ). The presence of abnormal fabrics could have a primary origin, resulting from free rotation of the particles in a viscous fluid (Dragoni et al., 1997) or from the presence of single domain magnetite, which possess an inherently inverse fabric (Stephenson et al., 1986). A secondary origin, resulting from a post emplacement modification of the fabric by cooling or tectonic stresses, was pointed out by Elwood (1978) and Park et al. (1988).

The normal magnetic fabric is usually assumed as related to magma flow. Knight and Walker (1988) compared macroscopic surface features related to magma flow with the magnetic fabric, recognizing the coincidence between $K 1$ and the magma flow direction. Moreover, these authors verified that the magnetic foliation in samples from the two dyke margins presented an imbrication angle with the dyke walls. This means that $K 1$ is symmetrically disposed relative to the dyke plane, as a result of the velocity gradient close to the margins. That could allow inferring the sense of the magma flow. However, Khan (1962) and Elwood (1978) proposed the orientation of $K 2$ as an indicator of the direction of the magma flow in Icelandic dykes.

These aforementioned results lead several authors to constrain magma flow direction inferences only when a normal magnetic fabric was present (e.g. Rochette et al., 1991; Staudigel et al., 1992; Raposo, 1997; Varga et al., 1998). To improve the quality of the magnetic fab- ric data allowing magma flow interpretation, Tauxe et al. (1998) proposed a sampling strategy limited to $10 \mathrm{~cm}$ within of each margin.

To avoid doubts in choice of $K 1, K 2$ or in any intermediate direction of the magnetic foliation plane as the direction of the magmatic flow, Geoffroy et al. (2002) developed a model that uses the imbrication angle between magnetic foliation ( $K 1-K 2$ plane) and the dyke plane. The vector perpendicular to this angle projected along the dyke wall plane would correspond to the direction of magma flow. Callot and Guichet (2003) also made use of this method and demonstrated analytically (and usefully applied to East Greenland volcanic margin) that the angle between S/C magma flow structures (a composite fabric in which S stands for "schistosite" and C for "Cisaillement", as defined by Berthé et al., 1979) could erroneously lead to identification of $K 1$ as an indication of the magma flow direction. The same authors point the magnetic zone axis (Henry, 1997) as a discriminate procedure in cases where $K 1$ could not be used to infer magma flow.

With this work we intent to contribute to the understanding of magma flow and emplacement of thick, deep-seated dykes. Therefore, we chose the great dyke of Foum-Zguid (Southern Morocco) for our study. Our sampling strategy aimed at the characterization of the magnetic fabric and bulk magnetic properties across and along the length of the dyke. The distance of each sample to the dyke wall was measured, with the objective of studying the evolution of the magnetic properties along sections across the dyke.

A total of 230 samples divided between nine sampled sites were collected and analyzed by magnetic methods, being petrographic analyses preformed for seven of these samples. These nine sites are located within a ca. $100 \mathrm{~km}$ long segment of the Foum-Zguid dyke.

\section{Geological setting}

The great dyke of Foum-Zguid is a vertical, NE-SW trending igneous structure (Fig. 1), which crosscuts Precambrian and Paleozoic host rocks of the Anti-Atlas belt in southern Morocco (Hollard, 1973; Leblanc, 1974). It is approximately $200 \mathrm{~km}$ long and $100 \mathrm{~m}$ thick in average, and it has remained tectonically stable since emplacement time (Marcais and Choubert, 1956).

According to Aarab et al. (1994), the tholeiitic magma of the Foum-Zguid dyke underwent a differentiation trend, leading to the presently observed gradual transition from mafic to felsic rocks, from the margin to the center. Such transition corresponds to fractional crystallization from dolerite at the margins to granophyres at the center, generated by transverse magmatic differentiation during emplacement, with symmetrical crystallization processes from the margins to the center. 


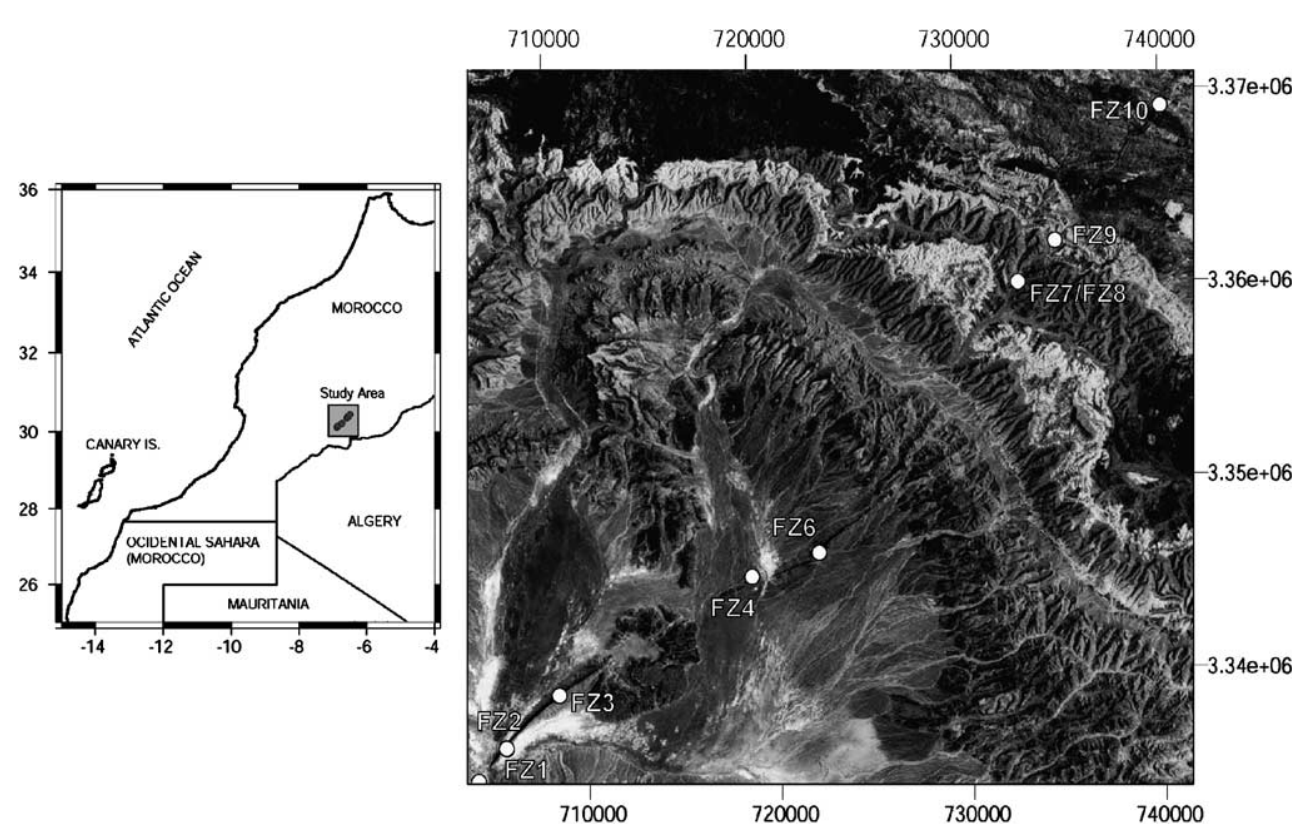

Fig. 1. Geographical location of the studied area (left) and Landsat TM image of the Foum-Zguid dyke in UTM coordinates displaying the sampled sites (right).

The Jurassic age of the dyke was obtained using two radiometric methods, suggesting an age of $196.9 \pm 1.8$ Ma by ${ }^{40} \mathrm{Ar} /{ }^{39} \mathrm{Ar}$ (Sebai et al., 1991) and $186-191 \mathrm{Ma}$ by K/Ar on whole rock (Hailwood and Mitchell, 1971). The Foum-Zguid dyke is related to the opening of the Central Atlantic Ocean, during the break-up of Pangea (Schermerhorn et al., 1978; Schott et al., 1981; Sebai et al., 1991). It belongs to a large magmatic province, which includes the Messejana dyke in Iberia, the Ksi-Ksou dyke in Algeria, the Taoudenni dykes in north Mali, and other volcanic intrusions in Iberia, North Africa, eastern margin of North America and northern part of South America.

\section{Petrography}

The large outcrop FZ-8 was chosen to perform detailed petrographic analysis along a cross-section, because of excellent exposure and the possibility to accurately measure distances to the dyke margin. Seven samples were selected among all the specimens collected in the field, according to their magnetic properties (see Section 5): FZ8-16A $(d=0.5 \mathrm{~m})$, FZ8-19A $(d=1.0 \mathrm{~m})$, FZ8-20A $(d=1.25 \mathrm{~m})$, FZ8-23 $(d=1.85 \mathrm{~m})$ and FZ8$25 \mathrm{~A}(d=3.0 \mathrm{~m})$, FZ8-1A $(d=9.8 \mathrm{~m})$, FZ8-9A $(d=21.2$ $\mathrm{m})$.

In general, there is no significant variation in the mineralogical composition showed by these seven samples, though important textural differences were recognized (in size, shape, and arrangement of the rock forming minerals), which can be ascribed to cooling processes.
The main minerals are plagioclase, forming either (micro-) phenocrysts or developing a tightly packed groundmass network, clinopyroxene (diopside-hedenbergite, sometimes as microphenocrysts) and pigeonite that may include formerly developed olivine grains. The interstitial rock matrix infilling comprises mainly magnetite, ilmenite, hornblende and biotite, the silicates representing the most important hydrated phases later formed in the course of magmatic crystallisation. In the matrix, accessory amounts of apatite and quartz can also be found, the latter silicate being quite rare and only recognized in samples near de dyke wall. Micrometric sulphide grains (chalcopyrite and pyrite) are invariably present in the examined samples as randomly distributed disseminations.

On the basis of their petrographical characteristics, the examined samples can be classified as dolerites, usually with intersertal-intergranular textures; in samples farthest from the dyke margin (FZ8-1A and FZ8-9A), the rock granularity is clearly coarser, showing welldeveloped interstitial granophyric infillings (Fig. 2). Evidence for late-magmatic, low- $T$, transformations can be found in some samples, reflecting the variable progress of hydrolysis, hydration and oxidation processes that lead to the alteration of some primary minerals, namely of plagioclase, pyroxene, biotite, hornblende and magnetite. The effects of late oxidation processes in magnetite grains are quite variable (from sample to sample and even at the microscale of a single specimen). Given the mineralogical features of these rocks, a titanomagnetitic nature is expected for the spinel phase observed, which is also compatible with the ilmenite exsolution lamellae 
(A)

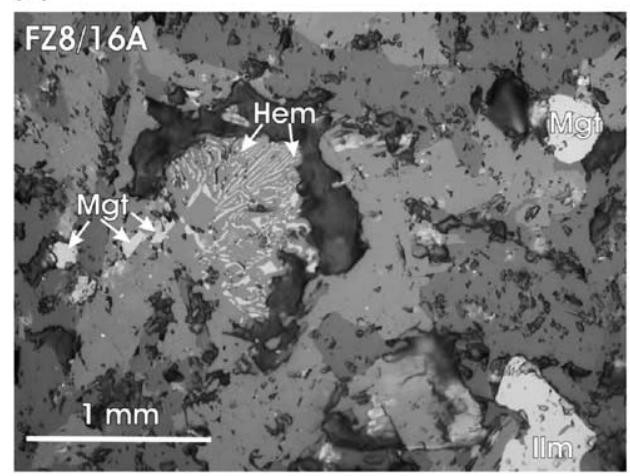

(B)
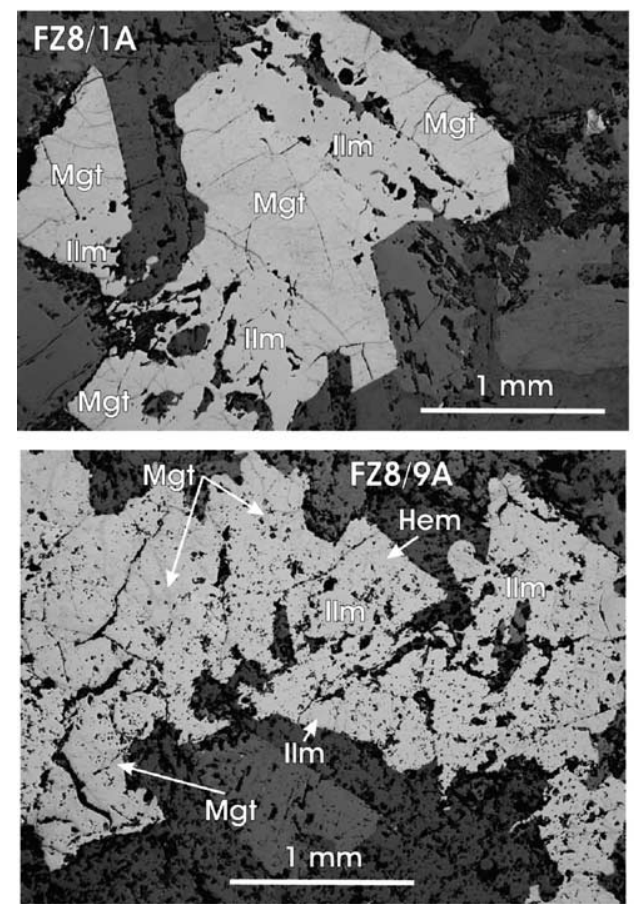
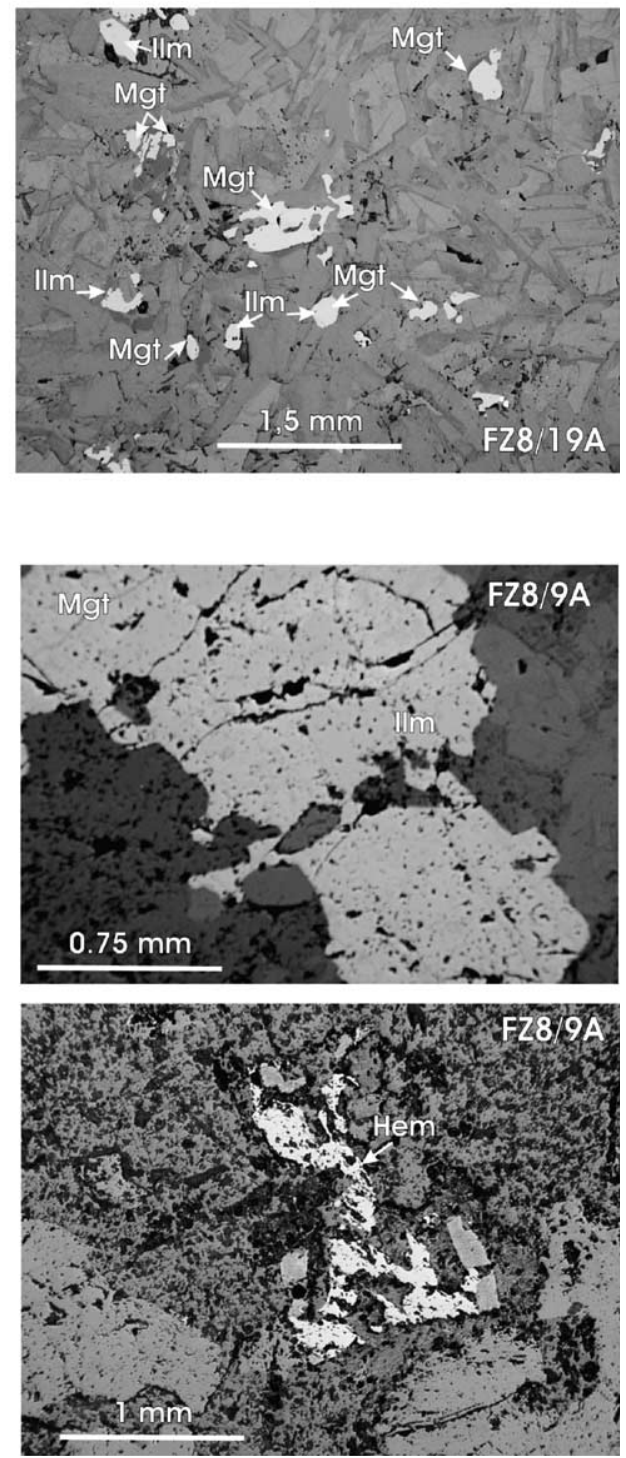

Fig. 2. Typical textural arrangements of oxide grains in samples FZ8-16A and FZ8-19A from the margin of the dyke (A) and in samples FZ8-1A and FZ8-9A toward the center of the dyke (B) as observed under simply polarized light in reflected microscopy. Mgt—magnetite; Ilm—ilmenite; Hemhematite.

observed in some samples. In samples far from the dyke margin (FZ8-1A and FZ8-9A), plagioclases are somewhat cloudy; the reasons for this require further detailed investigation with high-resolution microscopy. However, this optical effect can be due to the presence of sub-microscopic magnetite grains exsolved during slow rock cooling.

The presence of magnetite alignments along the cleavage planes of some silicates (biotite, in particular) is observed, and is interpreted as the result of late magmatic differentiation.

The petrographical analysis revealed the following main characteristics of the main magnetic carriers along the cross-section: (i) in samples near the margin (FZ8-16A and FZ8-19A), magnetite and ilmenite form separate grains (Fig. 2A); magnetite grains are sub-millimetric, represent no more than $2-5 \%$ of the total rock volume, are often corroded and show incipiently developed hematite fringes; hematite intergrowths with products of late silicate transformations can also be observed. (ii) In samples farther from the margin (FZ8-1A and FZ8-9A), ilmenite occurs only as exsolution lamellae within magnetite grains (Fig. 2B). These oxides make up $\approx 5-7 \%$ of the total rock volume, are sub-millimetric to millimetric in dimension and irregular in shape, and usually form interstitial clusters. Alignments of micrometric magnetite grains along the cleavage planes of some silicates were also observed. Evidence of late oxidation experienced by magnetite (locally very strong) can as well be found within many 
grains, irrespectively of their occurrence (interstitial clusters or alignments); in rare alignments, hematite prevails over magnetite.

\section{Magnetic carriers}

The main magnetic phases were analyzed by thermomagnetic analyses (susceptibility in low magnetic field with CS23 furnace apparatus coupled to KLY-2 susceptibilimeter) performed up to a maximum temperature of $700{ }^{\circ} \mathrm{C}$ under Argon controlled atmosphere. The magnetic domain distribution was studied with high field measurements made with a translation inductometer within an electromagnet.

Most of the thermomagnetic curves of 20 analyzed dolerite samples are characterized by a single magnetic phase shown by the reversible character of loops (see example of dashed cycle in Fig. 3). The Curie temperatures $\left(555 \pm 10{ }^{\circ} \mathrm{C}\right)$ are in agreement with a low-Ti titanomagnetite, almost pure magnetite, as the main magnetic carrier (O'Reilly, 1984). The high bulk magnetic susceptibility values ( $K$, mainly ranging between 19 and 27 in $10^{-3} \mathrm{SI}$ ) are consistent with such a ferromagnetic phase. Although most thermomagnetic cycles are almost reversible, some samples display a magnetic susceptibility peak followed by a drop during the heating run for temperatures between 320 and $450{ }^{\circ} \mathrm{C}$ (Fig. 3 ). In these cases, partial thermomagnetic runs reveal non-reversibility of the Curie curves for temperatures higher than $350{ }^{\circ} \mathrm{C}$. Such characteristics suggest the existence of chemical transformations, possibly corresponding to inversion from maghemite to hematite (Dunlop and Özdemir, 1997). However, since the mineralogical alterations resulted only in a smooth decrease of susceptibility during the heating at temperatures higher

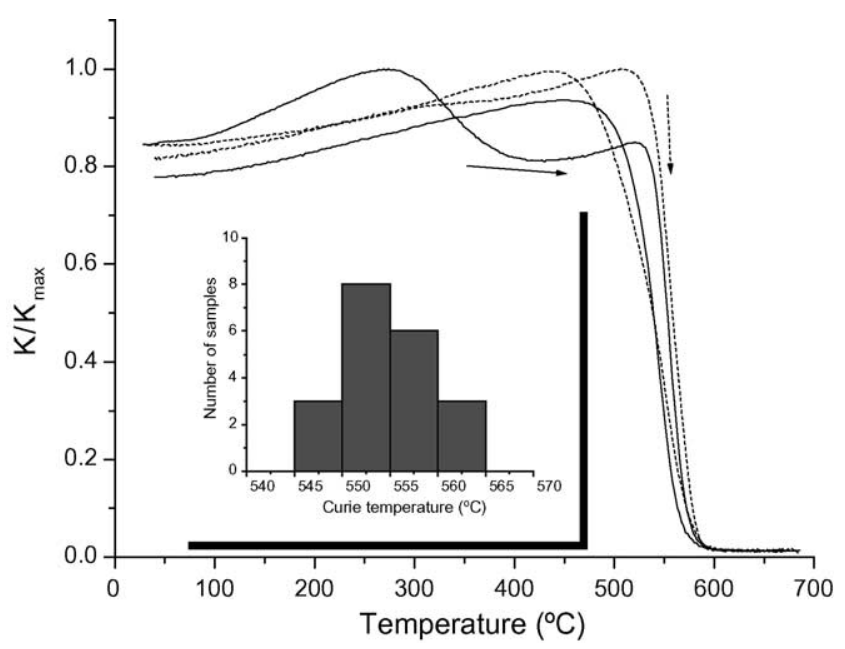

Fig. 3. Two examples of thermomagnetic curves performed in Argon controlled atmosphere: variation of the normalized susceptibility in low field $\left(K / K_{\max }\right)$ versus temperature. than $320{ }^{\circ} \mathrm{C}$, the large drop of susceptibility observed for values around $555 \pm 10{ }^{\circ} \mathrm{C}$ cannot be explained by these transformations, and Ti-poor titanomagnetite was therefore not formed during the heating run. Both petrographic and magnetic properties analyses show identical results for the main magnetic carriers.

High field measurements were performed for a total of 76 samples, with the objective of evaluating the hysteresis parameters. The Day diagram (Day et al., 1977; Dunlop, 1986a,b) shows that the grain size of the main magnetic phase (titanomagnetite) is in the pseudosingle-domain (PSD) range (Fig. 4). To verify if a significant contribution of multi-domain (MD) grains existed, we plotted the remanent coercivity (Hcr) versus the magnetization ratio $(\mathrm{Jrs} / \mathrm{Js})$, as proposed by Carlut and Kent (2002). Hcr values are very low (Fig. 5), in agreement with a significant contribution of MD grains. We did not find evidence of single domain (SD) magnetic grains and, therefore, no inverse magnetic fabrics are expected (Stephenson et al., 1986; Potter and Stephenson, 1988).

\section{Magnetic properties along cross-sections}

The sampling strategy had the objective to take, whenever possible, a sufficient amount of samples to accurately characterize the magnetic properties along sections across the dyke. We chose samples from sites FZ2, FZ7, FZ8 and FZ9 (see Fig. 1 for locations), based on the wider distance range and on measurement accuracy.

For FZ8, the samples were collected at distances between 0.3 and $30.5 \mathrm{~m}$ from the SE dyke margin. Samples near the margin, for a distance approximately less then $1.1 \mathrm{~m}$, show natural remanent magnetization (NRM) intensity values well grouped between 0.4 and $0.6 \mathrm{~A} / \mathrm{m}$, while for larger distances, higher values are observed, reaching a maximum of $1.5 \mathrm{~A} / \mathrm{m}$ (Fig. 6C). A continuous increase of the NRM intensity with distance to the margin can be observed in the graph. Although not so clear, a similar pattern is observed for the bulk magnetic susceptibility $(K)$ values. However, the $K$ values are strongly scattered for the samples located near the margin. A similar pattern can be observed in the FZ2 and FZ9 cross-sections (see Fig. 6A and D, respectively), for both NRM and K. For the FZ7 site, the same magnetic parameters appear scattered at the center of the dyke, being difficult to identify a trend of these magnetic parameters with distance to the margin (see Fig. 6B).

We also studied the variation of the coercive ratio $(\mathrm{Hcr} / \mathrm{Hc})$ along the cross-sections, which is sensitive to the variation of the magnetic grain size (e.g., Day et al., 1977; Dunlop, 1986a,b). Two distinct and consistent behaviors were observed (Fig. 7). Samples located near the contact, until approximately $2.0-3.0 \mathrm{~m}$ within 


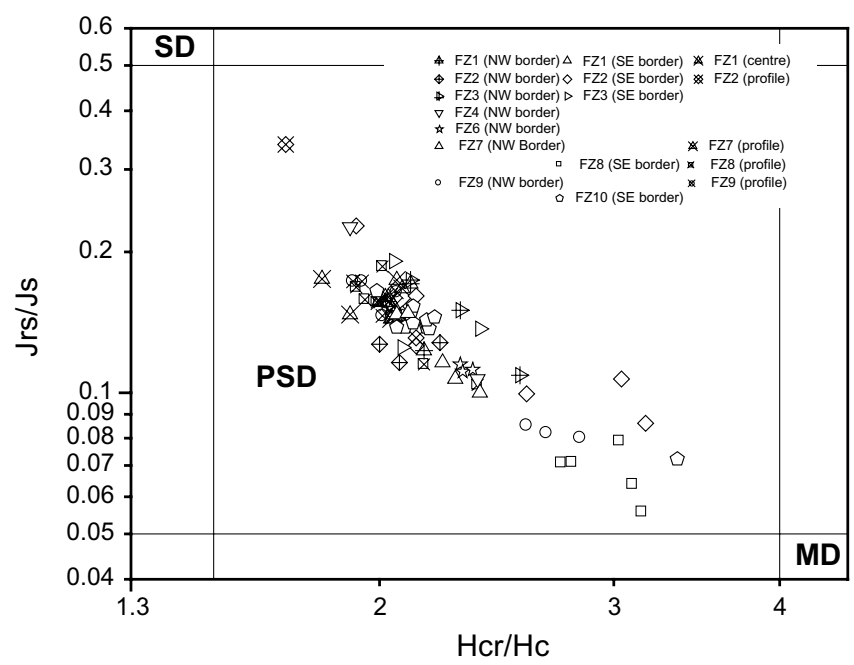

Fig. 4. Plot of Jrs/Js versus Hcr/Hc (Day et al., 1977), for the dolerite samples of Foum-Zguid dyke: single domain (SD), pseudo-single domain (PSD) and multi-domain (MD). The relative position of the samples in the dyke for each sampled site is indicated in brackets.

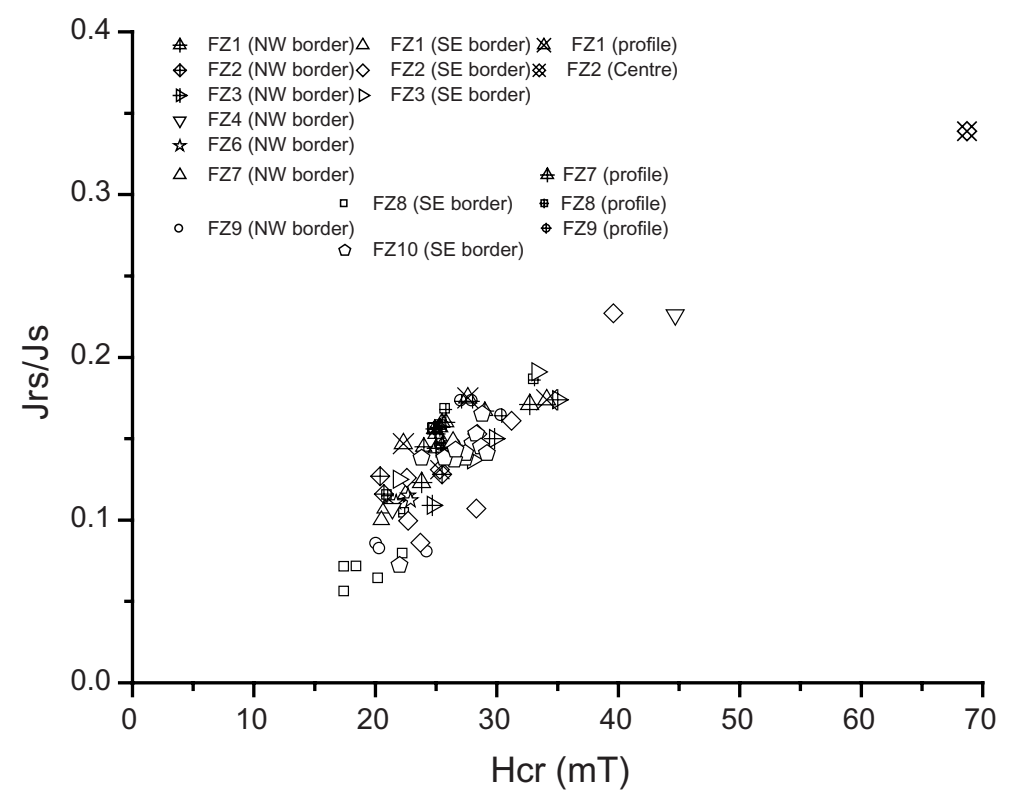

Fig. 5. Plot of Hcr versus Jrs/Js, for the dolerite samples of the Foum-Zguid dyke. The relative position of the samples in the dyke is given in brackets.

the dyke, display a considerable variation of the coercive ratio. Otherwise, samples located further from the margin display small variations of the coercive ratio, with a smooth decrease with increasing distance to the margin.

\section{Magnetic fabric}

For the interpretation of the magnetic fabric, we used the Jelinek's (1978) statistics for second-order tensors to determine the principal axes of the magnetic susceptibility ellipsoid and their confidence ellipse. The AMS ellip- soid is defined by a second-order tensor, being the principal magnetic susceptibility ellipsoid axes defined as $K 1 \geqslant K 2 \geqslant K 3$. To characterize the AMS ellipsoid, we used Jelinek's (1981) parameters. The statistical result of the AMS is related to the preferred orientation of the anisotropy of the individual particles (crystalline and shape anisotropy) in rock (Tarling and Hrouda, 1993; Borradaile and Henry, 1997).

The distribution of $K 3$ at some sites allowed the determination of the magnetic zone axis. The analyses interpretation, for the choice of this significant zone axis, follows the methodology of Henry (1997). This 

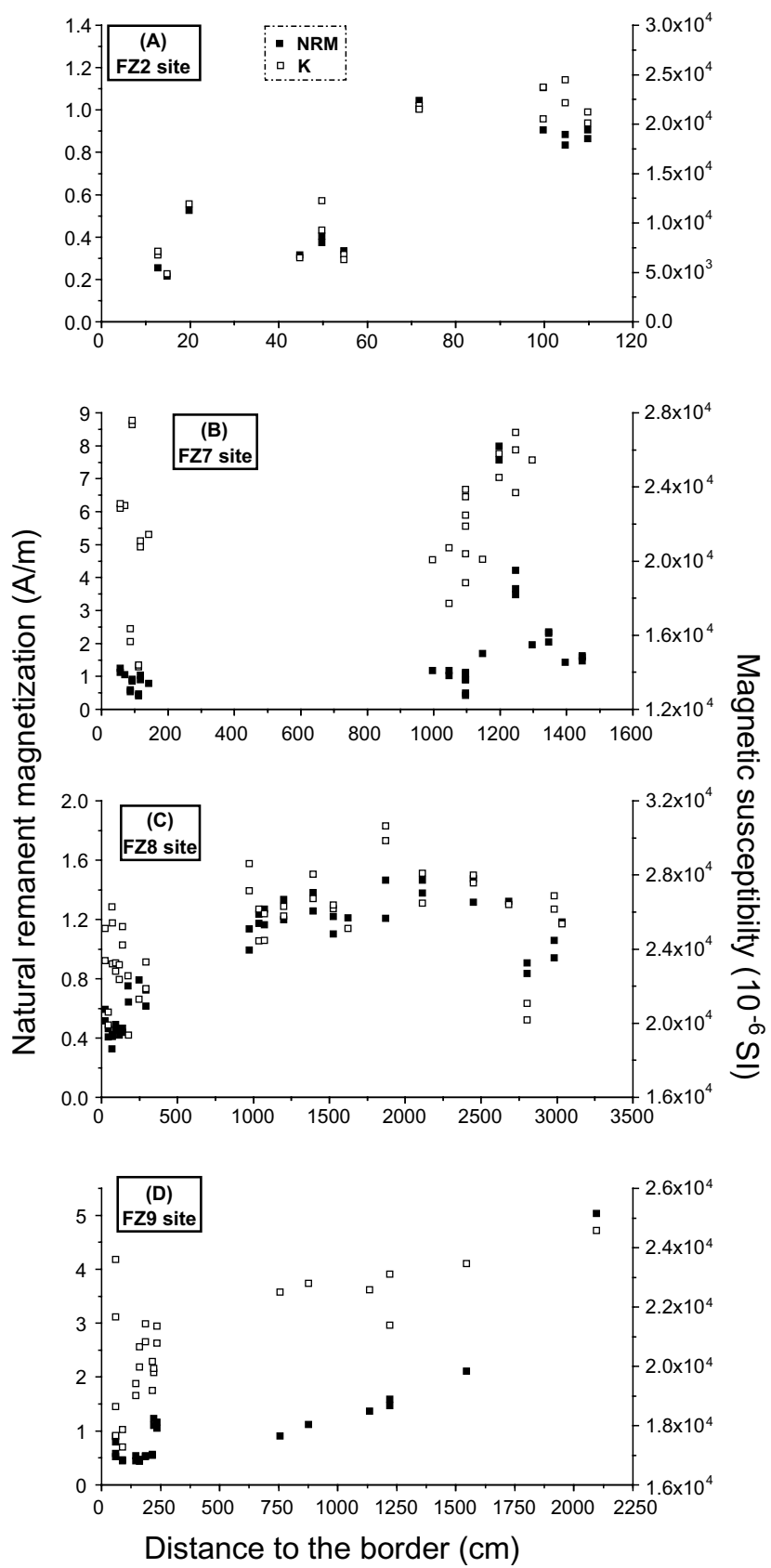

Fig. 6. Plot of Natural Remanent Magnetization (NRM) and bulk magnetic susceptibility $(\mathrm{K})$ versus the distance to the margin, for sites FZ2 (A), FZ7 (B), FZ8 (C) and FZ9 (D).

method generates 10.000 bootstrap re-samplings, obtaining density contours, which determine confidence zones at $95 \%$ and $63 \%$. This method, applied to all sites, revealed well-constrained density contours at $95 \%$ and $63 \%$ of the zone axis only for sites FZ6_NW, FZ8_SE1 and FZ9_NW.

To infer magma flow from petrofabric, we followed the method of Geoffroy et al. (2002), which is based on the intersection between the dyke wall and magnetic foliation plane, without considering the orientation of either $K 1$ or $K 2$. In cases where we have very low imbri-

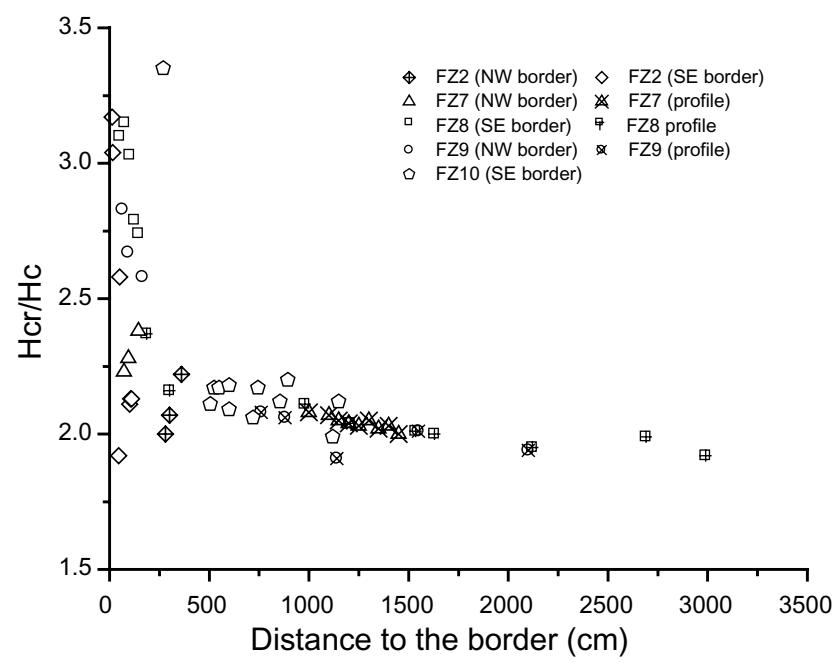

Fig. 7. Plot of the Hcr/Hc versus the distance to the margin for the dolerite samples of the Foum-Zguid dyke. The relative position of the samples in the dyke is given in brackets.

cation angles and/or a considerable dispersion of $K 3$ axes, this method fails and no significant information on flow directions can be obtained.

As referred to in the last section, bulk magnetic properties vary with distance to the margin. The magnetic fabric of each site was also analyzed as a function of the distance to the dyke margin. Therefore, each site was split into sub-sites corresponding to the samples located near the margins and samples located along profiles in the center of the dyke (see Table 1).

A first observation allows concluding for the presence of a normal magnetic fabric, (i.e., $K 3$ sub parallel to the pole of the dyke walls; Rochette et al., 1991, 1992; Tauxe et al., 1998). This is particularly true for samples located near the margin (Fig. 8).

Samples located near the margin of the dyke, corresponding to sub-sites FZ1_NW, FZ2_NW, FZ2_SE, FZ3_NW, FZ3_SE, FZ4_NW, FZ6_NW, FZ7_NW, FZ8_SE and FZ9_NW, display magnetic susceptibility ellipsoids with well grouped principal axes, showing well constrained confidence ellipses (see Fig. 8). Samples located farther from the margin present a higher dispersion, expressed by larger confidence ellipses. In fact there is a weak trend of increasing difference between $K 3$ and the pole of the dyke wall plane (both declination and inclination), from the margins towards the center of the dyke (Fig. 9). The sites that display such characteristics, although the data are very scattered, are FZ1_PR, FZ8_PR, FZ9_PR and FZ10_SE, corresponding to samples located along profiles within the dyke. Site FZ7_PR, clearly displays scattered data.

Considering only samples near the margins, we observe a clear relationship between the intersection of the dyke plane and the magnetic foliation, with $K 1$ axis. When the angle between these two planes is sufficiently 
Table 1

Magnetic properties of sampled sites

\begin{tabular}{|c|c|c|c|c|c|c|c|c|c|}
\hline Site & Dyke $(D / I)$ & $d(\mathrm{~m})$ & $K 1(D / I)$ & $K 3(D / I)$ & Inter & $\operatorname{NRM}(\mathrm{A} / \mathrm{m})$ & $K\left(10^{-3} \mathrm{SI}\right)$ & $P^{\prime}$ & $T$ \\
\hline FZ1 & $40 / 90$ & & & & & & & & \\
\hline $\begin{array}{l}\text { FZ1_SE } \\
\text { (SE border) }\end{array}$ & $40 / 90$ & $<3$ & $73 / 32$ & $335 / 17$ & $220 / 54$ & $\begin{array}{l}0.6 \pm 0.12 \\
(n=6)\end{array}$ & $\begin{array}{l}15.5 \pm 3.2 \\
(n=6)\end{array}$ & $\begin{array}{l}1.018 \pm 0.007 \\
(n=6)\end{array}$ & $\begin{array}{l}0.458 \pm 0.231 \\
(n=6)\end{array}$ \\
\hline $\begin{array}{l}\text { FZ1_NW } \\
\text { (NW border) }\end{array}$ & $40 / 90$ & $<2$ & $300 / 78$ & $132 / 11$ & $40 / 10$ & $\begin{array}{l}0.67 \pm 0.32 \\
(n=8)\end{array}$ & $\begin{array}{l}15.4 \pm 4.1 \\
(n=8)\end{array}$ & $\begin{array}{l}1.025 \pm 0.007 \\
(n=8)\end{array}$ & $\begin{array}{l}0.433 \pm 0.236 \\
(n=8)\end{array}$ \\
\hline $\begin{array}{l}\text { FZ1_PR } \\
\text { (profile) }\end{array}$ & & center & $284 / 51$ & $66 / 29$ & $220 / 59$ & $\begin{array}{l}0.76 \pm 0.16 \\
(n=7)\end{array}$ & $\begin{array}{l}14.4 \pm 3.7 \\
(n=7)\end{array}$ & $\begin{array}{l}1.024 \pm 0.011 \\
(n=7)\end{array}$ & $\begin{array}{l}-0.065 \pm 0.453 \\
(n=7)\end{array}$ \\
\hline FZ2 & $45 / 90$ & & & & & & & & \\
\hline $\begin{array}{l}\text { FZ2_SE1 } \\
\text { (SE border) }\end{array}$ & $45 / 90$ & $<0.6$ & $322 / 66$ & $135 / 22$ & $45 / 0$ & $\begin{array}{l}0.34 \pm 0.09 \\
(n=9)\end{array}$ & $\begin{array}{l}7.87 \pm 2.59 \\
(n=9)\end{array}$ & $\begin{array}{l}1.014 \pm 0.004 \\
(n=9)\end{array}$ & $\begin{array}{l}0.415 \pm 0.214 \\
(n=9)\end{array}$ \\
\hline $\begin{array}{l}\text { FZ2_SE2 } \\
\text { (SE border) }\end{array}$ & $45 / 90$ & $0.6-1.2$ & $18 / 59$ & $115 / 6$ & $225 / 73$ & $\begin{array}{l}0.94 \pm 0.1 \\
(n=8)\end{array}$ & $\begin{array}{l}21.8 \pm 1.5 \\
(n=8)\end{array}$ & $\begin{array}{l}1.019 \pm 0.004 \\
(n=8)\end{array}$ & $\begin{array}{l}0.537 \pm 0.209 \\
(n=8)\end{array}$ \\
\hline $\begin{array}{l}\text { FZ2_NW } \\
\text { (NW border) }\end{array}$ & $45 / 90$ & $3-4.0$ & $55 / 78$ & $173 / 8$ & $45 / 76$ & $\begin{array}{l}0.6 \pm 0.09 \\
(n=11)\end{array}$ & $\begin{array}{l}19.1 \pm 1.7 \\
(n=11)\end{array}$ & $\begin{array}{l}1.038 \pm 0.007 \\
(n=11)\end{array}$ & $\begin{array}{l}0.418 \pm 0.139 \\
(n=11)\end{array}$ \\
\hline FZ3 & $40 / 90$ & & & & & & & & \\
\hline $\begin{array}{l}\text { FZ3_SE } \\
\text { (SE border) }\end{array}$ & $35 / 90$ & $<2$ & $170 / 63$ & $316 / 25$ & $215 / 23$ & $\begin{array}{l}1.19 \pm 0.79 \\
(n=15)\end{array}$ & $\begin{array}{l}22.3 \pm 2.9 \\
(n=15)\end{array}$ & $\begin{array}{l}1.016 \pm 0.005 \\
(n=15)\end{array}$ & $\begin{array}{l}0.222 \pm 0.385 \\
(n=15)\end{array}$ \\
\hline $\begin{array}{l}\text { FZ3_NW } \\
\text { (NW border) }\end{array}$ & $60 / 90$ & $<3$ & $247 / 9$ & $334 / 16$ & $240 / 13$ & $\begin{array}{l}0.87 \pm 0.14 \\
(n=8)\end{array}$ & $\begin{array}{l}24.8 \pm 3.5 \\
(n=8)\end{array}$ & $\begin{array}{l}1.012 \pm 0.003 \\
(n=8)\end{array}$ & $\begin{array}{l}0.050 \pm 0.535 \\
(n=8)\end{array}$ \\
\hline FZ4 & $45 / 90$ & & & & & & & & \\
\hline $\begin{array}{l}\text { FZ4_NW } \\
\text { (NW border) }\end{array}$ & $45 / 90$ & $<2$ & $258 / 2$ & $168 / 5$ & $45 / 81$ & $\begin{array}{l}0.98 \pm 0.31 \\
(n=6)\end{array}$ & $\begin{array}{l}21.9 \pm 2.7 \\
(n=6)\end{array}$ & $\begin{array}{l}1.021 \pm 0.008 \\
(n=6)\end{array}$ & $\begin{array}{l}0.416 \pm 0.300 \\
(n=6)\end{array}$ \\
\hline FZ6 & $70 / 90$ & & & & & & & & \\
\hline $\begin{array}{l}\text { FZ6_NW } \\
\text { (NW border) }\end{array}$ & $70 / 90$ & $<3$ & $73 / 4$ & $338 / 41$ & $73 / 15$ & $\begin{array}{l}0.41 \pm 0.14 \\
(n=15)\end{array}$ & $\begin{array}{l}13.8 \pm 4.80 \\
(n=15)\end{array}$ & $\begin{array}{l}1.017 \pm 0.006 \\
(n=15)\end{array}$ & $\begin{array}{l}-0.022 \pm 0.346 \\
(n=15)\end{array}$ \\
\hline FZ7 & $44 / 90$ & & & & & & & & \\
\hline $\begin{array}{l}\text { FZ7_NW } \\
\text { (NW border) }\end{array}$ & $44 / 90$ & $<1.5$ & $42 / 31$ & $304 / 12$ & $44 / 40$ & $\begin{array}{l}0.79 \pm 0.27 \\
(n=12)\end{array}$ & $\begin{array}{l}20.6 \pm 4.6 \\
(n=12)\end{array}$ & $\begin{array}{l}1.03 \pm 0.007 \\
(n=12)\end{array}$ & $\begin{array}{l}0.015 \pm 0.435 \\
(n=12)\end{array}$ \\
\hline $\begin{array}{l}\text { FZ7_PR } \\
\text { (Profile) }\end{array}$ & & $10-15$ & $26 / 24$ & $141 / 44$ & $44 / 8$ & $\begin{array}{l}2.16 \pm 1.97 \\
(n=24)\end{array}$ & $\begin{array}{l}22.6 \pm 2.8 \\
(n=16)\end{array}$ & $\begin{array}{l}1.02 \pm 0.006 \\
(n=16)\end{array}$ & $\begin{array}{l}0.083 \pm 0.449 \\
(n=16)\end{array}$ \\
\hline FZ8 & $44 / 90$ & & & & & & & & \\
\hline $\begin{array}{l}\text { FZ8_SE1 } \\
\text { (SE border) }\end{array}$ & $44 / 90$ & $<1.5$ & $53 / 56$ & $145 / 2$ & $44 / 81$ & $\begin{array}{l}0.44 \pm 0.06 \\
(n=13)\end{array}$ & $\begin{array}{l}23.4 \pm 1.8 \\
(n=13)\end{array}$ & $\begin{array}{l}1.032 \pm 0.007 \\
(n=13)\end{array}$ & $\begin{array}{l}-0.285 \pm 0.174 \\
(n=13)\end{array}$ \\
\hline $\begin{array}{l}\text { FZ8_SE2 } \\
\text { (SE border) }\end{array}$ & $44 / 90$ & $1.5-3.0$ & $43 / 27$ & $135 / 1$ & $44 / 61$ & $\begin{array}{l}0.7 \pm 0.07 \\
(n=5)\end{array}$ & $\begin{array}{l}21.6 \pm 1.5 \\
(n=5)\end{array}$ & $\begin{array}{l}1.014 \pm 0.002 \\
(n=5)\end{array}$ & $\begin{array}{l}0.18 \pm 0.303 \\
(n=5)\end{array}$ \\
\hline $\begin{array}{l}\text { FZ8_PR } \\
\text { (Profile) }\end{array}$ & & $9.0-30.0$ & $36 / 1$ & $306 / 34$ & $44 / 11$ & $\begin{array}{l}1.2 \pm 0.17 \\
(n=25)\end{array}$ & $\begin{array}{l}26.3 \pm 2.3 \\
(n=25)\end{array}$ & $\begin{array}{l}1.021 \pm 0.008 \\
(n=25)\end{array}$ & $\begin{array}{l}0.255 \pm 0.389 \\
(n=25)\end{array}$ \\
\hline FZ9 & $44 / 90$ & & & & & & & & \\
\hline $\begin{array}{l}\text { FZ9_NW } \\
\text { (NW border) }\end{array}$ & $44 / 90$ & $<2.5$ & $23 / 73$ & $141 / 9$ & $44 / 40$ & $\begin{array}{l}0.72 \pm 0.29 \\
(n=14)\end{array}$ & $\begin{array}{l}19.7 \pm 1.7 \\
(n=14)\end{array}$ & $\begin{array}{l}1.024 \pm 0.006 \\
(n=14)\end{array}$ & $\begin{array}{l}-0.024 \pm 0.414 \\
(n=14)\end{array}$ \\
\hline $\begin{array}{l}\text { FZ9_PR } \\
\text { (Profile) }\end{array}$ & & $7.0-21.0$ & $333 / 42$ & $146 / 31$ & $44 / 21$ & $\begin{array}{l}1.92 \pm 1.41 \\
(n=7)\end{array}$ & $\begin{array}{l}22.9 \pm 1.0 \\
(n=7)\end{array}$ & $\begin{array}{l}1.016 \pm 0.006 \\
(n=7)\end{array}$ & $\begin{array}{l}0.0133 \pm 0.450 \\
(n=7)\end{array}$ \\
\hline FZ10 & $31 / 90$ & & & & & & & & \\
\hline $\begin{array}{l}\text { FZ10_PR } \\
\text { (Profile) }\end{array}$ & & $2.5-9.0$ & $209 / 1$ & $299 / 17$ & $31 / 5$ & $\begin{array}{l}1.03 \pm 0.23 \\
(n=14)\end{array}$ & $\begin{array}{l}22.4 \pm 4.3 \\
(n=14)\end{array}$ & $\begin{array}{l}1.022 \pm 0.008 \\
(n=14)\end{array}$ & $\begin{array}{l}0.169 \pm 0.341 \\
(n=14)\end{array}$ \\
\hline
\end{tabular}

Dyke (mean strike (str) and dip of the dyke wall), $d$ (distances in meters of the samples to the dyke margin), $K 1$ (mean declination $D$ and inclination $I$ of the maximum susceptibility axis), $K 3$ (mean declination $D$ and inclination $I$ of the minimum susceptibility axis), Inter (declination $D$ and inclination $I$ of the intersection between the dyke wall and magnetic foliation plane), NRM (Natural Remanent Magnetization), $K$ (Bulk magnetic susceptibility), $P^{\prime}$ (corrected degree of anisotropy) and $T$ (shape parameter of the magnetic susceptibility ellipsoid).

large to define a meaningful intersection, $K 1$ appears to be either parallel or perpendicular to this intersection (cf. Fig. 8). Moreover, the magnetic fabric is more oblate when $K 1$ is perpendicular to the intersection (Fig. 10). The observed relation between $K 1$ direction for the samples near the dyke margins and the direction of the inter- 


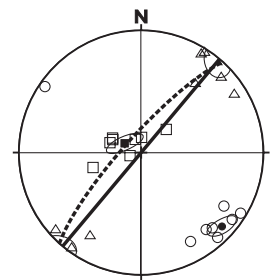

FZ1_NW (NW border)

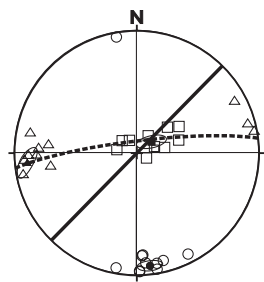

FZ2_NW (NW border)

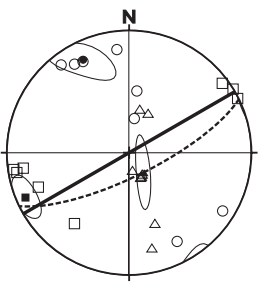

FZ3_NW (NW border)

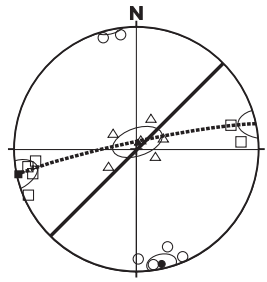

FZ4_NW (NW border)

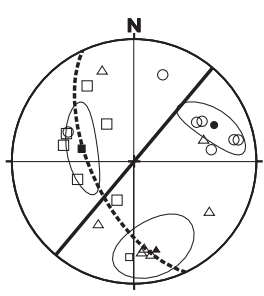

FZ1_PR (Profile)

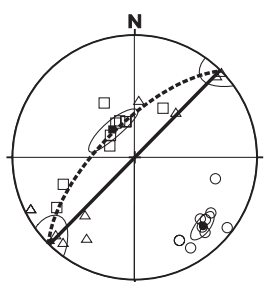

FZ2 SE1 (SE border)

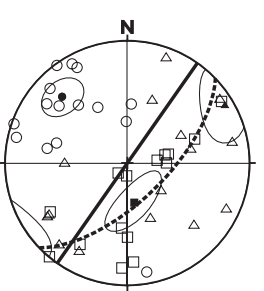

FZ3_SE (SE border)

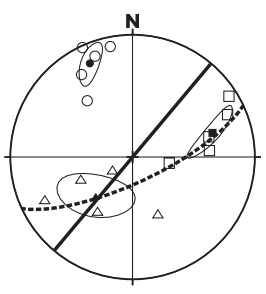

FZ1_SE (SE border)

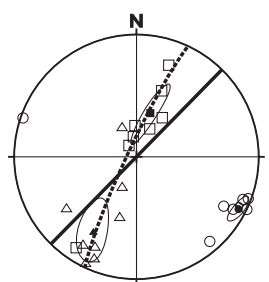

FZ2_SE2 (SE border)

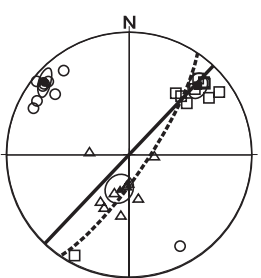

FZ7_NW (NW border)

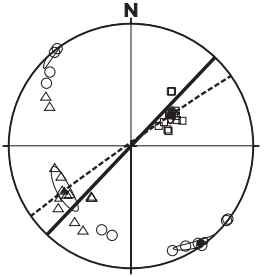

FZ8_SE1 (SE Border)

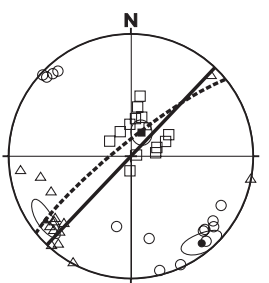

FZ9_NW (NW Border)

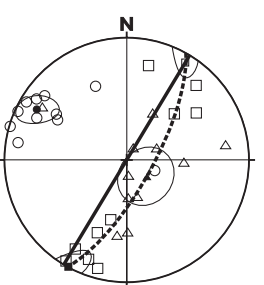

FZ10_PR (Profile)

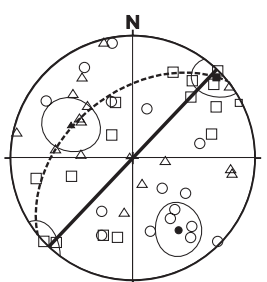

FZ7_PR (Profile)

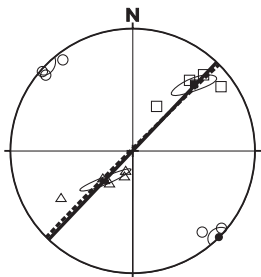

FZ8_SE2 (SE Border)

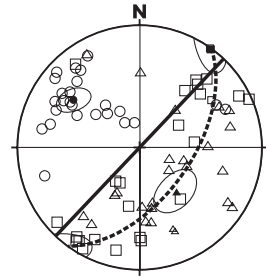

FZ8_PR (Profile)

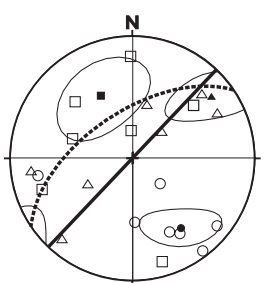

FZ9_PR (Profile)

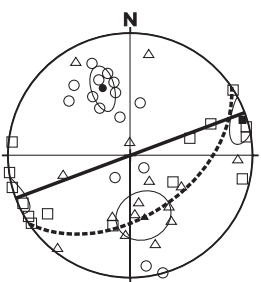

FZ6_NW (NW border)

Fig. 8. Stereographic projection (Schmidt equal area projection, lower hemisphere). For the different sites, minimum (circles), intermediate (triangle) and maximum (square) susceptibility axes in the samples (open symbols) and in mean (full symbols) with their $95 \%$ confidence ellipse. Thicker solid line represents the dyke plane at each sampled site. Dashed line represents the magnetic foliation plane.

section between magnetic and dyke planes, with the shape of the magnetic susceptibility ellipsoid, were already observed in intrusions with complex flow conditions (Henry, 1980).

The sites that yield clear information to infer the magma flow based on the amplitude of imbrication angle between the magnetic foliation and dyke plane are FZ2_SE1, FZ2_SE2, FZ2_NW and FZ4_NW. Although the imbrication angle is not so high in sites FZ1_NW and FZ7_NW as for the other sites, the well-defined and small confidence ellipse for $K 3$ axis allows the application of Geoffroy et al. (2002) methodology. For sites FZ1_NW, FZ2_SE1 and FZ7_NW, upwards magma flow can be inferred, while for FZ2_SE2, FZ2_NW and FZ4_NW a sub-horizontal magma flow can be deduced.

\section{Discussion and conclusions}

The main magnetic carrier is a Ti-low titanomagnetite phase with a dominant PSD magnetic grain size. These characteristics prevail in all sampled sites. Based on the evolution of the coercive ratio along cross-sections, a decrease of the size of the main magnetic carrier is observed for samples located farther from the margin (Fig. 7). This characteristic is also evidenced on the Day diagram, where samples located nearest the margin systematically display higher values of the coercive ratio for each sampled site (Fig. 4). Such observation is unexpected in a dyke where the finest grain size should correspond to the faster cooled margin. However, for samples far from the margin, the presence of (i) millimetric magnetite with ilmenite lamellae, (ii) coronitic magnetite 


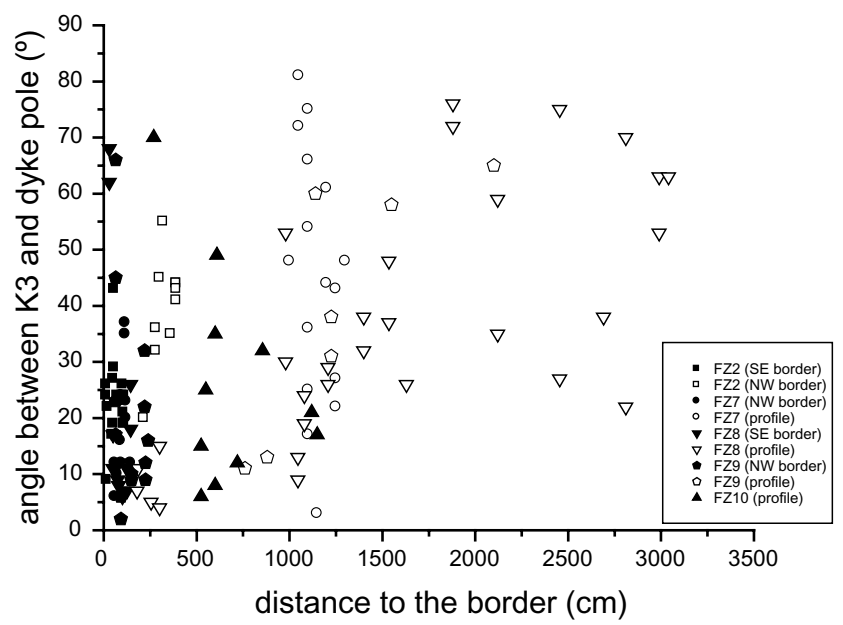

Fig. 9. Plot of the angular difference between the minimum principal axes of the magnetic susceptibility ellipsoids $(K 3)$ and pole of the dyke plane versus the distance to the margin.

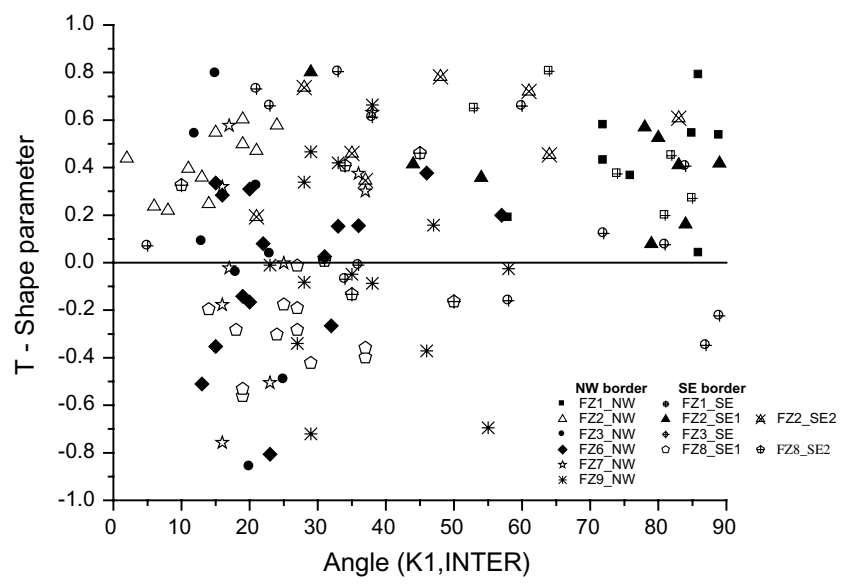

Fig. 10. Plot of the shape parameter of the magnetic susceptibility ellipsoid $(\mathrm{T})$ versus the angular difference between $K 1$ axes and the intersection of magnetic foliation with dyke plane.

oxidation and (iii) sub-microscopic magnetite grains along cleavage planes of some silicates are, in our opinion, the most probable factors that determine a magnetic signal that culminates in a magnetic signature representative of smaller grains. Ilmenite lamellae within spinel leads in fact to an efficient partition of the pristine coarse oxide grain into several portions, actually decreasing significantly the dimension and spatial arrangement of the magnetic carriers. Coronitic alteration of magnetite to hematite also shrinks effectively the size of the magnetic grain.

As shown above, the magnetic fabric is normal, although an increase of the dispersion of the principal axes of the magnetic ellipsoid is observed with distance to the margin of the dyke. Post-emplacement magmatic differentiation and/or late hydrothermal transformations gave a more complex fabric within the internal part of the dyke (Henry and Meurisse, 1978). Therefore, to infer flow direction from the magnetic fabric, only samples from the dyke margin should be used.

From the stereographic analyses of the samples located near the dyke margins, it was possible to infer sub-horizontal magma flow for sites FZ2_SE2, FZ2_NW and FZ4_NW, and an upwards magma flow for sites FZ1_NW, FZ2_SE1 and FZ7_NW.

The samples of FZ2 collected at the margin (FZ2_SE1 and FZ2_SE2, see Table 1), display distinct NRM values in the first $1.2 \mathrm{~m}$, which are in agreement with different magnetic fabrics. In fact, for the first 0.6 $\mathrm{m}$, where the values of NRM are around $0.2-0.6 \mathrm{~A} / \mathrm{m}$ (Fig. 6), the magnetic fabric agrees with a sub-vertical magma flow (FZ2_SE1 in Fig. 8). However, for distances between 0.6 and $1.2 \mathrm{~m}$, the NRM intensity is higher (between 0.8 and $1.2 \mathrm{~A} / \mathrm{m}$ ) and the magnetic fabric suggests a sub-horizontal magma flow (FZ2_SE2 in Fig. 8). These characteristics point out a different evolution farther from the fast cooled margin, probably related to late magma displacement within the magma chamber.

At sites FZ6_NW, FZ8_SE1 and FZ9_NW, where very low imbrication angles and/or enlarged confidence ellipses for $K 3$ axes has been defined, a coherent application of such methodology cannot be done, and, therefore, no conclusive results can be obtained in terms of the magma flow vector. Moreover, $K 1$ principal axes are sub-parallel to the zone axes in FZ6_NW and FZ8_SE1 (cf. Fig. 8), and make an angular difference of $35^{\circ}$ in FZ9_NW; therefore, according to Henry (1997), the magnetic lineation may, at least in part, be due to the intersection of different mineral structural planes. These three sites display, additionally, distinct shapes of the magnetic susceptibility ellipsoid when compared with the remaining sampled sites, with the exception of FZ7_NW. Site FZ8_SE1 shows a prolate magnetic fabric, while in the other two a variation between the oblate and prolate shapes is observed.

Recently, Callot and Guichet (2003) revealed that the magnetic fabric could be related to angular relationships between two preferential mineral alignments, as a result of complex flow. A major consequence is that the inference of $K 1$ as the marker of flow direction could be erroneous. The reported characteristics for FZ6_NW, FZ8_SE1 and FZ9_NW could, in fact, result only from the angle between two preferential mineral planar alignments.

\section{Acknowledgments}

This work is a contribution to research projects GEOMODELS (POCTI/CTA/38695/2001) and TEAMINT (POCTI/CTA/48137/2002). The authors would like to thank the Centre National de la Recherche Scien- 
tifique (CNRS - France) and Gabinete de Relações Internacionais da Ciência e do Ensino Superior (GRICES-Portugal) for funding. We thank C. Catita, A. Palencia, R. Vegas, A. Touil, for collaboration in the fieldwork.

\section{References}

Aarab, E.M., Rahimi, A., Rocci, G., 1994. Un exemple de différenciation transverse: le Grand Dyke de Foum Zguid (Anti-Atlas, Maroc). C.R. Acad. Sci. Paris 319 (série II), 209-215.

Aifa, T., Lefort, J.-P., 2001. Relationship between dip and magma flow in Saint-malo dolerite dyke swarm (Britany, France). Tectonophysics 331, 169-180.

Aifa, T., Lefort, J.P., Guennoc, P., 1999. Anisotropy of magnetic susceptibility investigations of the St Malo dyke swarm (Brittany, France): emplacement mechanism of doleritic intrusions. Geophys. J. Int. 139, 573-582.

Archanjo, C.J., Araújo, M.G.S., Launeau, P., 2002. Fabric of the Rio Ceará-mirin mafic dike swarm (northeastern Brazil) determined by anisotropy of magnetic susceptibility and image analysis. J. Geophys. Res., 107 B3, NO. B3, 10.1029.

Berthé, D., Choukroune, P., Jegouzo, P., 1979. Orthogneiss, mylonites and non-coaxial deformation of granites: the example of the South Armorican shear zone. Journal of Structural Geology 1, 3142.

Borradaile, G.J., Henry, B., 1997. Tectonic applications of magnetic susceptibility and its anisotropy. Earth-Sci. Rev. 42, 49-93.

Callot, J.P., Guichet, X., 2003. Rock texture and magnetic lineation in dykes: a siple analytical model. Tectonophysics 366, 207-222.

Callot, J.P., Geoffroy, L., Auborg, C., Pozzi, J.P., Mege, D., 2001. Magma flow directions of shallow dykes from the East Greenland volcanic margin inferred from magnetic fabric studies. Tectonophysics 335, 313-329.

Carlut, J., Kent, D.V., 2002. Grain-size-dependent paleointensity results from very recent mid-oceanic ridge basalts. J. Geophys. Res. 107 (B3), 2049

Day, R., Fuller, M., Schmidt, V.A., 1977. Hysteresis properties of titanomagnetites: grain size and compositional dependence. Phys. Earth Planet. Interiors 13, 260-267.

Dragoni, M., Lanza, R., Tallarico, A., 1997. Magnetic anisotropy produced by magma flow: theoretical model and experimental data from Ferrar dolerite sills (Antarctica). Geophys. J. Int. 128, 230 240.

Dunlop, D.J., 1986a. Hysteresis properties of magnetite and their dependence on particle size: a test of pseudo-single-domain remanence models. J. Geophys. Res. 91, 9569-9584.

Dunlop, D.J., 1986b. Coercive force and coercivity spectra for submicron magnetites. Earth Planet. Sci. Lett. 78, 288-295.

Dunlop, D.J., Özdemir, Ö., 1997. Rock Magnetism: Fundamentals and frontiers. Cambridge University Press pp. 573.

Elwood, B.B., 1978. Flow and emplacement direction determined for selected basaltic bodies using magnetic susceptibility anisotropy measurements. Earth Planet. Sci. Lett. 41, 254-264.

Geoffroy, L., Callot, J.P., Auborg, C., Moreira, M., 2002. Magnetic and plagioclase linear fabric discrepancy in dykes: a new way to define the flow vector using magnetic foliation. Terra Nova 14 , 183-190.

Hailwood, E.A., Mitchell, J.G., 1971. Paleomagnetic and radiometric dating results from Jurassic intrusions in South Morocco, Geophys. J.R. Astron. Soc. 24, 351-364.

Hargraves, R.B., Johnson, D., Chan, C.Y., 1991. Distribution anisotropy: the cause of AMS in igneous rocks?. Geophys. Res. Lett. 18, 2193-2196.
Henry, B., 1980. Contribution à l'étude des propriétés magnétiques de roches magmatiques des Alpes: conséquences structurales, régionales et générales. Trav. Lab. Tectonophysique Paris CRE 80/07, 528

Henry, B., 1997. The magnetic zone axis: a new element of magnetic fabric for the interpretation of the magnetic lineation. Tectonophysics $271,325-329$.

Henry, B., Meurisse, M., 1978. Mesures d'anisotropie de susceptibilité magnétique dans une ophite Pyrénéenne: détermination du mode de mise en place. Mem. BRGM 91, 457-463.

Hollard, E.A., 1973. La mise en place au Lias des dolerites dans le Paléozoique moyen du NE des plains du bassin de Tindouf (Sud de l'Anti/Atlas Central, Maroc). C.R. Acad. Sci. Paris 277 (serie D), 553-556.

Jelinek, V., 1978. Statistical processing of magnetic susceptibility measured in groups of specimens. Stud. Geoph. Geod. 22, 50-62.

Jelinek, V., 1981. Characterization of the magnetic fabric of rocks. Tectonophysics 79, 63-67.

Khan, M.A., 1962. The anisotropy of magnetic susceptibility of some igneous and metamorphic rocks. Journal of Geophysical Research 67 (7), 2874-2885.

Knight, M.D., Walker, G.P.L., 1988. Magma flow directions in dikes of the Koolau Complex, Oahu, determined from magnetic fabric studies. Journal of Geophysical Research 93 (B5), 4301-4319.

Leblanc, M., 1974. Le grand dyke de dolerites de l'Anti.Atlas et le magmatisme jurassique du Sud-Marocain. C.R. Acad. Sci. Paris 278 (serie D), 2943-2946.

Marcais, J., Choubert, G., 1956. Les grands traits de la géologie du Maroc. Lexique stratigraphique du Maroc, introduction géologique. Direction des Mines et de la Géologie, Rabat.

O'Reilly, W., 1984. Rock and Mineral Magnetism. Blackie 220pp.

Park, J.K., Tanczyk, E.I., Desbarats, A., 1988. Magnetic fabric and its significance in the 1400 Ma Mealy diabase dykes of Labrador, Canada. J. Geophys. Res., 13689-13704.

Potter, D., Stephenson, A., 1988. Single-domain particles in rocks and magnetic fabric analysis. Geophys. Res. Lett. 15, 1097-1100.

Rochette, P., Jenatton, L., Dupuy, C., Boudier, F., Reuber, L., 1991. Diabase dikes emplacement in the Oman ophiolite: a magnetic fabric study with reference to geochemistry. In: T. Peters (Ed.), Ophiolite genesis and evolution of the Oceanic Lithosphere. Minist. of Pet. and Miner., Sultanate of Oman, pp. 55-82.

Rochette, P., Jackson, M., Auborg, C., 1992. Rock magnetism and the interpretation of anisotropy of magnetic susceptibility. Rev. Geophys. 30, 109-226.

Rochette, P., Aubourg, C., Perrin, M., 1999. Is this magnetic fabric normal. A review and case studies in volcanic formations. Tectonophysics 307, 219-234.

Raposo, M.I.B., 1997. Magnetic fabric and its significance in the Florianópolis dyke swarm, southern Brazil. Geophys. J. Int. 131, 159-170.

Rubin, A.M., 1995. Propagation of magma-field cracks. Annu. Rev. Earth Planet. Sci. 23, 287-336.

Rubin, A.M., 1998. Dike ascent in partially molten rock. Journal of Geophysical Research 103 (B9), 20901-20919.

Schermerhorn, L.J.G., Priem, H.N.A., Boelrijk, N.A.I.M., Hebeda, E.H., Verdurmen, R.H., Verschure, E.A.Th., 1978. Age and origin of the Messejana Dolerite fault-dike system (Portugal and Spain) in the light of the opening of the North Atlantic Ocean. Journal of Geology 86, 299-309.

Schott, J.J., Montigny, R., Thuizat, R., 1981. Paleomagnetism and potassium-argon age of the Messejana Dike (Portugal and Spain): angular limitation to the rotation of the Iberian Peninsula since the Middle Jurassic. Earth Planet. Sci. Lett. 53, 457-470.

Sebai, A., Feraud, G., Bertrand, H., Hanes, J., 1991. 40Ar/39Ar dating and geochemistry of tholeiitic magmatism related to the early opening of the Central Atlantic rift. Earth Planet. Sci. Lett. 104, 455-472. 
Staudigel, H., Gee, J., Tauxe, L., Varga, R.J., 1992. Shallow intrusive directions of sheeted dikes in the Troodos ophiolite: anisotropy of magnetic susceptibility and structural data. Geology 20, 841-844.

Stephenson, A., Sadikum, S., Potter, D., 1986. A theoretical and experimental comparision of the susceptibility and remanence in rocks and minerals. Geophys. J.R. Astron. Soc. 84, 185-200.

Tarling, D.H., Hrouda, F., 1993. The Magnetic Anisotropy of Rocks. Chapman \& Hall 1-217.
Tauxe, L., Gee, J.S., Staudigel, H., 1998. Flow directions in dikes from anisotropy of magnetic susceptibility data: The bootstrap way. Journal of Geophysical Research 103 (B8), 1777517790.

Varga, R.J., Gee, J.S., Staudigel, H., Tauxe, L., 1998. Dike surface lineations as magma flow indicators within the sheeted dike complex of the Troodos ophiolite, Cyprus. Journal of Geophysical Research 103 (B3), 5241-5256. 